\title{
Opportunities for governors to align electricity markets with state energy goals
}

Electric utilities are facing a fundamental challenge to their long-
term viability. New categories of business models are emerging to
address challenges to utility profitability from rate-of-return regulation, adjustments to rate-of-return that reduce revenue loss, added profit opportunities, and transformative models. Governors can play an important role by convening stakeholders and encouraging thoughtful conversations and pilot programs to assess the options for managing the transitions underway in the electricity sector.

Sam Cramer $^{\mathrm{a}}$ and Aliza Wasserman ${ }^{\mathrm{b}}$

Sam Cramer is a Policy Analyst in the Environment, Energy \& Transportation Division of the National Governors Association Center for Best Practices. Mr. Cramer leads NGA's commercial property assessed clean energy (C-PACE) and green finance efforts, and also works on responsible shale energy development, new utility business models and electricity market structures, greenhouse gas emission plans, grid resiliency, and the energy-water nexus. Through research and writing he supports the development of issue briefs, technical assistance memos, webinars, and meetings. Mr. Cramer received his B.S. in Atmospheric Science from Cornell University and his M.P.P. in Environmental Policy from American University.

Aliza Wasserman serves as program director for the NGA Center for Best Practice's Environment, Energy \& Transportation Division. Ms. Wasserman works with governors' advisors to analyze and design state policies on an array of topics including utility business models, analyzing state pathways for federal greenhouse gas rules, energy efficiency, shale development and hydraulic fracturing, and water. Ms. Wasserman writes issue briefs and tailored memos to governors' offices, organizes educational forums for gubernatorial advisors, facilitates stakeholder engagement processes, and advises on state policy development. Ms. Wasserman holds a master's degree in Public Affairs from Princeton University and a bachelor's of arts from Rutgers University.

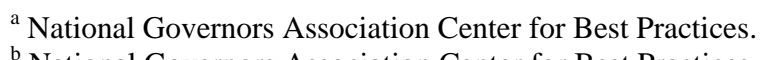

${ }^{\mathrm{b}}$ National Governors Association Center for Best Practices. 


\section{A changing industry: Implications for state policy}

The electricity sector is confronting new technologies, policies, and demands that are creating challenges for the traditional utility business model and providing opportunities for new energy technologies and services. A primary challenge to utilities' business models is the declining growth of electricity sales. Electricity demand is projected to increase at a rate of $1 \%$ per year, which is roughly half the historical rate. ${ }^{1}$ The U.S. Energy Information Administration has identified the main drivers for this reduced growth as higher energy efficiency standards, slowing population growth, and structural changes in the economy. ${ }^{2}$ At the same time, more and more corporations are purchasing clean energy, with $60 \%$ of Fortune 100 companies setting clean energy purchasing commitments, and those purchases are typically made even when regulated utilities have no opportunity to profit. ${ }^{3}$ In a recent survey, $97 \%$ of utility executives said they believed that their utility's business model must evolve, and executives generally viewed the existing regulatory model as the main obstacle to that evolution. ${ }^{4}$ A suite of new ideas from utility executives and thought leaders are beginning to emerge. ${ }^{5}$

In both regulated and restructured markets, utility business models are based on a 100year old model that was developed as the country was focused on promoting electrification. They concentrate on repaying investors for operating expenses and allowing investors to earn a return on prudent capital investments. In other words, the more power utilities sell and the more concrete they put in the ground, the more they earn. Some states have begun to change that model to reflect new goals and market developments, such as measures to decouple utilities' revenues from their sales volumes - but ratemaking continues to create incentives for utilities to invest capital in new transmission wire, distribution infrastructure, or power plants. Flat consumer demand and the growth of distributed energy resources such as rooftop solar, storage, and demand response may reduce the amount of power sold and the need for future utility capital investments, forcing a rethinking of current regulatory frameworks.

Thus far, most utilities have remained economically viable despite declining sales growth because of record high levels of capital expenses and their cost of capital has declined more slowly than the state-allowed rate of return (ROR). ${ }^{6}$ If state regulators eventually 
adjust the ROR to reflect the lower cost of capital, utilities will confront higher costs, declining sales, and lower profit margins. If utilities compensate by significantly increasing electricity rates, customers would have a greater incentive to find alternative sources of supply or reduce their demand (see the text box "Game-Changing Technologies"). That potential dynamic_-declining sales leading to higher costs leading to further declining sales — is referred to as the "utility death spiral."

Because utilities are state-regulated businesses that provide a basic necessity, state governments are being drawn into that issue, primarily through the debates underway in more than 20 state

legislatures and public utility commissions (PUCs) about rates for distributed solar ${ }^{7}$ debates that have often become heated among solar customers, solar businesses, environmentalists, utilities, and consumer advocates. Most of the responses states are pursuing, including value-ofsolar tariffs, increased fixed charges, and reduced rates for distributed solar, rebalance the payments between utilities and solar customers but do not

\section{Game-changing technologies}

The following technologies are changing the economic landscape for utilities:

- Distributed generation: Electric power generation on the customer side of the electric meter, primarily rooftop solar

- Energy efficiency: Technologies that use less energy to perform the same functions, such as LED lighting

- Demand response: Reductions in electricity demand and usage relative to normal consumption patterns in response to price signals, incentive payments or information

- Advanced metering infrastructure: An integrated system of smart meters and data-management systems that enables two-way communication between customers and electric utilities (or third-party providers); the detailed data can be used to increase energy efficiency and conservation

Technologies that may impact the system in the new future include:

- Advanced energy storage: As advanced technologies that can capture and store energy efficiently (such as batteries) become more affordable, they can store increasing amounts of energy from variable sources, such as wind and solar power, thereby dramatically increasing the functionality of those sources by allowing them to meet demand even when the wind is not blowing or the sun is not shining.

- The Internet of things: Having devices that are connected to each other and whose operations can be controlled over the internet allows greater system efficiency. For example, a "smart" thermostat can learn from a smartphone location when the house is unoccupied and can manage the home appliances to reduce wasteful demand.

resolve the more fundamental

underlying challenge of reduced utility profit opportunities.

Some analysts say that no additional incentives are needed and that utilities can manage the reduced demand for electricity by improving their cost management, instead. ${ }^{8}$ As economist Alfred Kahn observed, "All regulation is incentives," meaning that utilities are 
motivated to comply with state energy policies because otherwise they risk losing state regulatory protection. Other analysts say that the decoupling and solar net metering debates show that utilities may be willing to comply with state law but are also likely to oppose their expansion when those laws undermine their profitability. ${ }^{9}$

In states where policymakers choose to engage utilities as drivers of advanced technology, regulatory reforms are necessary. PUCs can pursue modest adjustments to utility business models, but commissioners typically interpret their statutory authority narrowly and are unlikely to pursue more fundamental reform without direction from governors and state legislatures. Governors can play a critical role in initiating conversations and providing policy direction for managing the rapid changes in this critical industry. 


\section{Markets and monopolies: Lessons from the streetcar and other}

\section{transformed industries}

The electricity sector is not the first regulated industry to face competition from new technologies. The cable television industry, for example, was a regulated monopoly that faced dramatic declines in sales when satellite TV emerged. State regulators did not protect existing cable monopolies from the new technology, and some companies went out of business, but the sector as a whole successfully diversified its offerings to add valuable new services such as internet and phone, which now make up the majority of the industry's revenue. ${ }^{10}$

In contrast, when the streetcar industry faced rising competition from buses and cars, it did not innovate its services. ${ }^{11}$ When a state commission declined to allow higher rates for one streetcar company, ensuring that the company would not recover some of its fixed costs, the company appealed the decision to the U.S. Supreme Court, arguing that public utilities had a constitutional right to recover the costs of the system they had built. The court, however, ruled that utility loses resulting from economic forces are not applicable to revenue recovery guarantees by state regulators. ${ }^{12}$

Electric utilities may not be able to depend on traditional regulatory structures to protect them from competition. To ensure their own viability, utilities may need to innovate and compete with third parties to provide value to customers. Historically, however, regulated monopolies in the electricity sector have invested very little in research and development compared to other industries. ${ }^{13}$ Technological and business model innovation in the sector is now driven by third-party companies that do not own or operate the grid and must seek utility or regulatory permission to access the electricity market. Learning from the experiences of other sectors, regulators should set clear guidance to ensure that third parties can fairly access customers. ${ }^{14}$ At the same time, states may want to consider the political and practical value of motivating utilities to pursue innovation as a vehicle to achieve state energy goals. Because the distribution wires remain a natural monopoly, however, there are strong public-interest reasons to continue some aspects of traditional utility regulation. 


\section{Categories of utility business models}

Utility business models generally fall into four categories (Table 1), with gradations and overlap existing in practice.

- ROR regulation: The basis of most regulatory systems used today, this model compensates utilities through rates set by a regulatory commission based on utilities' reasonable costs plus a return on their investments.

- Adjusted ROR regulation to reduce utility loss: This category model adjusts the ROR regulation to minimize utility revenue losses from declining sales.

- Added profit opportunities: This category model offers profit opportunities for utilities that deliver on outcomes important to customers and society, including clean energy.

- Transformative models: These utilities have forms dramatically different from U.S. regulatory systems, including through performance-based regulation, smart system integrators, and energy service utilities.

\begin{tabular}{|l|l|}
\hline Categories of Utility Business Models \\
\hline $\begin{array}{l}\text { Rate of Return } \\
\text { regulation }\end{array}$ & $\begin{array}{l}\text { Vertically integrated or restructured (with or without clean } \\
\text { energy standards) }\end{array}$ \\
\hline \multirow{4}{*}{$\begin{array}{l}\text { Adjusted ROR to } \\
\text { reduce utility loss }\end{array}$} & Decoupling or lost revenue adjustment mechanism \\
\cline { 2 - 2 } & Increased fixed charges \\
\cline { 2 - 2 } & Value-of-solar tariff \\
\cline { 2 - 2 } opportunities & Time-of-use rates \\
\hline \multirow{4}{*}{$\begin{array}{l}\text { Added profit } \\
\text { Transformative } \\
\text { Models }\end{array}$} & Ownership of assets \\
\cline { 2 - 2 } & Treat expense as assets (aka "regulatory asset") \\
\cline { 2 - 2 } & Partnerships with third-party providers \\
\cline { 2 - 2 } & Performance-based compensation \\
\hline & Performance-based regulation \\
\cline { 2 - 2 } & Smart system integrator \\
\cline { 2 - 2 } & Energy service utility \\
\hline
\end{tabular}

Table 1: The Four Categories of Utility Models

\section{ROR regulation}

The primary model today is called "rate of return" regulation because utilities are compensated through rates that a regulatory commission sets based on utilities' reasonable costs plus a return on equity (ROE) for investments in conventional generation, transmission and distribution assets. ${ }^{15}$ That model applies to both vertically 
integrated utilities and restructured utilities, although the latter are generally forbidden from or severely limited in owning generation.

Many states have augmented that basic model with policies to support greater use of clean energy, typically in the form of renewable portfolio standards (RPS) and energy efficiency portfolio standards. Clean energy standard expenses are typically recovered without an ROE, so utilities are not provided an incentive to go beyond the minimum standard.

\section{Adjusted ROR regulation to reduce utility loss}

As utilities have confronted declining sales growth, several methods have emerged to adjust the ROR model to allow utilities to recover their fixed costs, including decoupling, lost revenue adjustment mechanisms, increased fixed charges, and value-of-solar tariffs. In general, such adjustments do not address the fundamental issue-namely, that utilities can earn greater profits from investing in traditional capital-intensive technologies than from investing in advanced technologies that require less capital and more operational and labor resources.

\section{Added profit opportunities}

Regulators also can enable utilities to earn a profit from clean energy investments. One option is to allow utilities to own distributed clean energy generation assets and earn an ROR equal to or greater than what they would earn on traditional generation sources. ${ }^{16}$ Another option is to allow utilities to treat nonphysical clean energy expenses as a longterm capital asset, known as a "regulatory asset." For example, a utility investment in staff to implement efficiency upgrades could get an ROR even though it is a labor expense. Alternatively, regulators could let utilities invest in clean energy companies as non-regulated subsidiaries to diversify their revenue streams, which could help parent companies' profits but would not address regulated utilities' profits. Utilities could also implement joint ventures with clean energy firms to increase their capabilities in the clean energy sector and benefit from entrepreneurial approaches.

One emerging model is performance-based compensation (PBC), in which states compensate a utility for the quality of energy service it provides rather than the cost. PBC reorients utilities to focus on specific objectives rather than solely on encouraging investment in capital-intensive assets. A wide array of outcomes can be rewarded, 
including increased reliability, improved environmental performance, minimized costs, and improved customer service. ${ }^{17}$ Many states use some form of PBC for reliability performance, and about half of states partially use that approach for energy efficiency programs. States can use the model for renewable energy, as well. ${ }^{18}$ Within PBC, utilities can be compensated in many ways, including as a percentage of spending on clean energy programs, as a percentage of savings created for customers, as an extra profit margin for specific clean energy expenses, or as a bonus payment that seems fair. Determining a utility's authorized ROE is an art, not a science, and so regulators may end up deciding on a number that they feel would provide utilities with appropriate compensation for investing in clean energy and spur increased innovation from a historically risk-averse sector. Regulators concerned with cost containment can create a sliding scale that centers on the current ROE so that failing to meet performance expectations leads to lower than current ROE, while the higher ROE is paid only if the utility achieves higher performance. States that have employed some elements of PBC for energy efficiency include Arizona, Arkansas, California, Colorado, Connecticut, Georgia, Hawaii, Indiana, Kentucky, Massachusetts, Michigan, Minnesota, Missouri, New Hampshire, New Mexico, New York, North Carolina, Ohio, Oklahoma, Rhode Island, South Carolina, Texas, Vermont and Wisconsin. ${ }^{19}$

$* * * * * * * * * * * * * * * * * * * * * * * * * * * * * * \mathrm{BEGIN} \mathrm{SIDEBAR} * * * * * * * * * * * * * * * * * * * * * * * * * * * * * *$

\section{Colorado's shared earnings model}

Xcel Energy had more renewable energy credits than it needed to comply with Colorado's RPS in 2009 largely because of the low cost of wind energy. The utility wanted to sell its excess credits to other utilities, but state regulations barred it from doing so. In response, Xcel proposed a new form of renewable energy credit that allowed it to share the proceeds of those sales with ratepayers. The Colorado PUC approved a plan that divided the earnings from sales of renewable energy credits to give $80 \%$ back to customers and $20 \%$ to utility shareholders. Thus, the state created an incentivize for the utility to increase renewable energy production so that it could sell the excess credits and make additional profits, all while benefiting residents. ${ }^{20}$

$* * * * * * * * * * * * * * * * * * * * * * * * * * * * * * * \mathrm{END} \mathrm{SIDEBAR} * * * * * * * * * * * * * * * * * * * * * * * * * * * * * * *$ $* * * * * * * * * * * * * * * * * * * * * * * * * * * * * * \mathrm{BEGIN} \operatorname{SIDEBAR} * * * * * * * * * * * * * * * * * * * * * * * * * * * * * * *$

\section{Arizona's shared earnings model}


Arizona allows its largest electricity utility, Arizona Public Service Company, to earn a performance incentive from its energy efficiency programs based on the success of the utility in meeting its annual energy savings targets. It is structured as a tiered incentive, with a higher dollar per unit of energy saved for high levels of achievement, capped at $\$ 0.0125$ per kilowatt-hour saved. No incentive is provided for achieving energy savings below a minimum threshold. The amount of the incentive is calculated as a percentage of the net benefits the energy efficiency programs produce for ratepayers. In 2015, the utility surpassed the savings goal by 5\%, saving customers $\$ 60$ million. The utility earned $7 \%$ of net benefits and so was able to collect $\$ 5.3$ million in shareholder profits for successfully achieving those energy savings goals. ${ }^{21}$

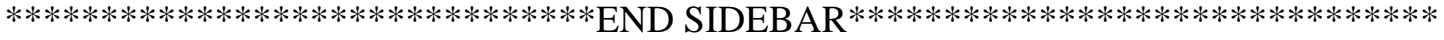

\section{Transformative models}

Some thought leaders are exploring transformative models for utility profitability, totally rethinking what utilities are and how they earn profits. Those models include

performance-based regulation (PBR), the utility as smart system integrator, and the utility as a provider of energy services.

Note that "performance-based regulation" is not the same as "performance-based compensation" (although the terms often are used interchangeably). This article applies the term performance-based regulation to a dramatically altered approach that affects the ROE for the entire utility enterprise, not just for a specific set of functions such as reliability or clean energy. ${ }^{22}$ The United Kingdom is pursuing a PBR model under its Revenues $=$ Incentives + Innovation + Outputs $(\mathrm{RIIO})$ approach, in which a regulatory staff of 800 oversee the complex development and monitoring of progress across a range of innovative performance incentive mechanisms.

Another transformative business model is the smart system integrator, which envisions a restructured utility that balances supply and demand with small-scale distributed resources, such as rooftop solar, combined heat and power, and demand response. Largescale generators continue to be major energy suppliers, but the smart system integrator focuses on incorporating technologies at the edge of the distribution grid located close to the point of consumption. In some formulations of the model, energy efficiency is left to the market or to nonutility program operators. This model could put the utility directly 
into competition with third parties that are not regulated and lack both public interest responsibility and public interest protections. New York's Reforming the Energy Vision $(\mathrm{REV})$ process is one example of a public policy driving new transformative business models in the clean energy economy (see text box "New York's REV Model as a Transformative Smart System Integrator").

$* * * * * * * * * * * * * * * * * * * * * * * * * * * * * * \mathrm{BEGIN} \mathrm{SIDEBAR} * * * * * * * * * * * * * * * * * * * * * * * * * * * * * *$

\section{New York's REV model as a transformative smart system integrator}

In 2014, New York Governor Andrew Cuomo launched a process of transitioning the state's utilities from their traditional role as providers of electricity transmission and distribution services to a new role as "distribution system platform providers," in the county's first transformation of utilities into smart system integrators. In these new roles, the utilities will become grid managers, coordinating and facilitating the increased use of distributed energy resources to create a cleaner, more reliable and more resilient grid. The state's public service commission is developing performance-based metrics tied to earnings mechanisms for achieving smart system integration goals. It is encouraging utilities to be innovative and proactive by allowing them to propose new pilot programs and incentive structures to test different ideas. The result will be a gradual shift by utilities toward a performance-based structure that encourages distributed resource adoption in a manner that is profitable for utilities. ${ }^{23}$

$* * * * * * * * * * * * * * * * * * * * * * * * * * * * * * * \mathrm{END} \operatorname{SIDEBAR} * * * * * * * * * * * * * * * * * * * * * * * * * * * * * * *$

Another potential type of transformative business model is referred to as an "energy service provider." In that model, the utility is compensated based on both the quantity and the quality of service it provides, such as lighting and heating, rather than on just the quantity of product it delivers. That model is more akin to the current telecom business model, where customers pay for services rather than for commodities. In the electricity sector, that means paying for lighting services rather than for kilowatt-hours. The model guarantees the utility a monopoly on the distribution portion of its business only, forcing the utility to compete on all other services, including generation of conventional and clean energy. $^{24}$ 


\section{Role for governors}

Governors can play a critical part in describing and promoting a vision for the role of utilities in advancing state policy goals and customer interests, including cleaner generation, more reliable power delivery, and lower bills. There is no clear single solution to the complex set of market challenges, and so a variety of state innovations may need exploration. Actions that governors could consider include establishing a task force, encouraging innovation through guidance, focusing on fair market access, promoting PBC pilots, and protecting consumers by clarifying stranded asset liability.

\section{Establish a task force to explore issues and make recommendations}

Governors can establish a task force to explore a series of issues, including the current electricity system limitations; misaligned utility incentives; and recommendations for regulation, executive action and legislation. Task force members can include state energy officials, public utility commissioners, utilities, clean energy companies, consumer advocates, environmental organizations, business and industry, technical experts, and legislative representatives. Nevada Governor Brian Sandoval issued an executive order in early 2016 creating a task force to provide recommendations on policies that will encourage clean energy development, advance grid modernization and grid resiliency, and support distributed generation and energy storage. The task force, which includes utility, environmental, industry and legislative stakeholders, will deliver a report with recommendations to the governor. ${ }^{25}$

\section{Encourage utility innovation through guidance documents}

The consensus of the academic literature on the role of government in addressing rapid technological and scientific advancement is that guidance is more appropriate than

rulemaking. ${ }^{26}$ Guidance documents are a low-cost mechanism for small PUCs. Governors can set policy goals on energy, environment, and economic development, and the PUCs can provide guidance to utilities on how to achieve those goals without advocating particular technologies or business models. PUCs can also open exploratory dockets to solicit input from utilities and other stakeholders. New York State has provided guidance to utilities on the outcomes desired and asked the utilities to propose the business models and compensation mechanisms they needed to achieve those outcomes. New Jersey's 
PUC has encouraged utilities to pilot the use of energy storage by partnering with third parties.

\section{Focus on fair market access for all businesses}

Much of the innovation in the electricity sector is being driven by new market entrants that need access to utilities' infrastructure and ratepayers. Utilities may try to erect barriers to prevent new players accessing the market, such as delaying interconnection requests, limiting the size of resources that third parties can provide or limiting thirdparty access to customers or customer data. Learning from other sectors in which monopolists faced technological innovation, regulators should ensure that entrants have fair access to the market. ${ }^{27}$

One guiding principle is the longstanding prohibition on "undue discrimination" in utility rates. That prohibition is rooted in preventing anticompetitive practices, such as a utility favoring a particular ratepayer with a special rate. State regulators may be able to use that existing prohibition in state laws to correct unfair procedures that block new entrants from participating in regulatory proceedings and to open utility infrastructure to thirdparty service providers. ${ }^{28}$ Governors can help regulators by publicizing the public benefits of fair market access and can direct executive branch staff to intervene in regulatory dockets to encourage PUCs to consider that principle.

\section{Promote pilots for PBC}

As noted earlier, PBC can help utilities meet specific performance objectives, adapt to new market conditions, and earn additional revenue. There is a bipartisan interest in this model that shifts the focus away from costs and toward outcomes. Governors can ask PUCs to help utilities develop PBC pilot programs, potentially even specifying the objectives to prioritize. A body of literature is emerging on how to design PBC targets, and governors can encourage utilities and PUCs to explore those insights. States are exploring a similar effort in the health care field as they develop "value-based purchasing" pilots and metrics. Governors can encourage conversations between health and energy officials in their states to share lessons on piloting PBC models. 


\section{Review stranded asset liability to establish strong consumer protection provisions}

States can adjust utilities' incentives to align with state energy goals, but they should do so with an eye toward consumer protection. For example, there is a risk that fossil-based resources could become underutilized assets, given the significant technology and policy changes underway in the sector. Historically, PUCs have passed most utilities' underutilized asset costs on to consumers because they felt that the utilities had made investment decisions that were initially prudent but because of the changing market, economic or technological circumstances ultimately became uneconomic. As mentioned with regard to streetcars, however, precedent exists for states no longer to grant regulated utilities confronting economic competition the same level of economic guarantees they had previously received. The current rapid pace of technological change in the electricity sector makes the risk of "stranded assets" greater than in the past. Governors and PUCs may want to review and update state laws and regulations on "used and useful" to account for the pace of change. In proceedings to review utility investments in new generation infrastructure, governors could request that PUCs assess the risk that the assets will not be beneficial in the long run. PUCs could also review and update their regulatory guidelines on utilities' and consumers' shares of the costs for underutilized assets, such as by updating integrated resource planning guidance or modifying depreciation rates. 


\section{Conclusion}

Utilities are facing a perfect storm of declining growth in electricity sales, growing competition, and customers' increasing use of distributed energy. The current utility regulatory model may need to adapt to today's realities. Because investor-owned utilities are state-regulated entities, the state is critical in managing those adjustments. A range of ideas, both evolutionary and revolutionary, can reorient utility revenue streams and business models. Governors can play an important role by convening stakeholders and encouraging thoughtful conversations and pilot programs to assess the options for managing the transitions underway in the electricity sector.

\section{Acknowledgments}

The National Governors Association Center for Best Practices thanks the following individuals for editorial review and valuable input: Lisa Schwartz and Andy Satchwell of Lawrence Berkeley National Laboratory; Rich Sedano of the Regulatory Assistance Project; Sonia Aggarwal of America's Power Plan; Ken Costello of the National Regulatory Research Institute; Ari Peskoe of the Harvard Law School Environmental Policy Initiative, and John Sterling of the Smart Electric Power Alliance.

This article was funded through a grant by the U.S. Department of Energy's Office of Energy Efficiency and Renewable Energy and Office of Electricity, as well as the Heising-Simons Foundation.

\footnotetext{
${ }^{1}$ U.S. Energy Information Administration, “Annual Energy Outlook 2013,” Today in Energy, https://www.eia.gov/todayinenergy/index.cfm?tg=aeo2013\%20(annual\%20energy\%20outlook\%202013)htt ps://www.eia.gov/todayinenergy/index.cfm?tg=aeo2013\%20(annual\%20energy\%20outlook\%202013) (accessed June 13, 2016).

${ }^{2}$ U.S. Energy Information Administration, "U.S. Economy and https://www.eia.gov/todayinenergy/detail.cfm?id=10491Electricity Demand Growth."

${ }^{3}$ For information about corporate interest in and principles concerning clean energy purchasing, see the Corporate Renewable Energy Buyers' Principles website at http://buyersprinciples.org/aboutus/http://buyersprinciples.org/about-us.

${ }^{4}$ Utility Dive, 2016 State of the Electric Utility Survey.

${ }^{5}$ For instance, an array of white papers from utilities and thought leaders has been convened under the $51^{\text {st }}$ State initiative that Smart Electric Power Association has organized and posted at http://sepa51.org/. ${ }^{6}$ Data on the utility industry capital trends can be found in Edison Electric Institute, Financial Review 2016-Industry Financial Performance (Washington, DC: Edison Electric Institute, 2016).

${ }^{7}$ Benjamin Innskeep et al., The 50 States of Solar: Q1 2016 Quarterly Report (Raleigh, NC: Clean Energy Technology Center, 2016), https://nccleantech.ncsu.edu/n-c-clean-energy-technology-center-releases-q1solar-policy-update-to-the-50-states-of-solar-2 (accessed Sept. 14, 2016).

${ }^{8}$ For instance, cost savings can be achieved by (1) raising the productivity at the front line (for example, optimized communications), (2) reducing external spending (for example, taking advantage of
} 
purchasing power across divisions), (3) restructuring and streamlining organizations and (4) pruning assets through periodic portfolio reviews (for example, shifting to low-cost fuels, locking in long-term fuel contracts). Utilities can take those steps on their own, or utility regulators can encourage them. In addition, utility regulators can encourage steps to optimize the larger grid with efforts that reduce costs for utilities. Examples of grid-wide efficiency improvements are listed in Steven Nadel and Garrett Herndon, "The Future of the Utility Industry and the Role of Energy Efficiency," American Council for an EnergyEfficient Economy Summer Study on Energy Efficiency in Buildings (2014), p. 22-24, http://aceee.org/files/proceedings/2014/data/papers/8-138.pdf (accessed Sept. 14, 2016).

${ }^{9}$ Ron Binz and Ron Lehr, "Utilities 2020: Exploring Utility Business Models and the Regulatory Changes Needed to Transform Them," http://www.rbinz.com/Utilities\%202020.pdf (accessed September 14, 2016).

${ }^{10}$ E. Graffy, "Disruptive Competitionhttp://www.seventhwave.org/sites/default/files/elj-articlesummary2.pdf."

${ }^{11}$ Ibid.

${ }^{12}$ Market Street Railroad Co. v. Railroad Commission, 324 U.S. 548 (1945).

${ }^{13}$ Ken Costello, A Primer on R\&D in the Energy Utility Sector (Silver Spring, MD: National Regulatory Research Institute, 2016), http://nrri.org/download/nrri-16-05-rd-in-energy-utilitysector/http://nrri.org/download/nrri-16-05-rd-in-energy-utility-sector (accessed September 14, 2016).

${ }^{14}$ John E. Kwoka Jr., "Twenty-Five Years of Deregulation: Lessons for Electric Power," Loyola University of Chicago Law Journal 33, no. 885 (2002http://lawecommons.luc.edu/luclj/vol33/iss4/11/): 885, http://lawecommons.luc.edu/luclj/vol33/iss4/11 (accessed Sept. 14, 2016).

${ }^{15}$ Andrew Satchwell et al., A Framework for Organizing Current and Future Electric Utility Regulatory and Business Models (Berkeley, CA: Lawrence Berkeley National Laboratory, 2015), https://emp.lbl.gov/sites/all/files/lbnl-181246_0.pdf (accessed Sept. 14, 2016).https://emp.lbl.gov/sites/all/files/lbnl-181246_0.pdf

${ }^{16}$ Steve Kihm et al., You Get What You Pay For: Moving Toward Value in Utility Compensation. Part 1Revenue and Profit (San Francisco: America's Power Plan, 2015), http://americaspowerplan.com/wpcontent/uploads/2014/10/CostValue-Part1-Revenue.pdfhttp://americaspowerplan.com/wpcontent/uploads/2014/10/CostValue-Part1-Revenue.pdf (accessed September 14, 2016).

${ }^{17}$ For more information about designing incentive mechanisms, see Energy Innovation Policy \& Technology, "Going Deep on Performance-Based Regulation," http://energyinnovation.org/resources/ourpublications/going-deep-performance-based-regulation (accessed Aug. 5, 2016).

${ }^{18}$ For further information about principles of designing performance-based compensation structures, see Sonia Aggarwal and Eddie Burgess, New Regulatory Models (San Francisco: America's Power Plan, 2014), http://westernenergyboard.org/wp-content/uploads/2014/03/SPSC-

CREPC_NewRegulatoryModels.pdfhttp://westernenergyboard.org/wp-content/uploads/2014/03/SPSCCREPC_NewRegulatoryModels.pdf (accessed Sept. 14, 2016); and Melissa Whited, Tim Woolf, and Alice Napoleon, "Utility Performance Incentive Mechanisms: A Handbook for Regulators," Synapse Energy Economics Blog, entry posted March 12, 2015, http://www.synapse-energy.com/about-us/blog/synapsehandbook-provides-guidance-designing-implementing-utility-performance (accessed Sept. 14, 2016). ${ }^{19}$ Seth Nowak et al., Beyond Carrots for Utilities: A National Review of Performance Incentives for Energy Efficiency (Washington, DC: American Council for an Energy-Efficient Economy, 2015),

http://aceee.org/beyond-carrots-utilities-national-reviewhttp://aceee.org/beyond-carrots-utilities-nationalreview (accessed Sept. 14, 2016).

${ }^{20}$ S. Aggarwal, New Regulatory Models, (San Francisco: America's Power Plan, March 2014), http://westernenergyboard.org/wp-content/uploads/2014/03/SPSC-CREPC_NewRegulatoryModels.pdf, 10.

${ }^{21}$ The original performance incentive structure was established in 2005, and the Arizona Corporation Commission modified it in 2014 to change the cap from a percentage of spending on energy efficiency programs to a dollar-per-kilowatt-hour-saved cap. By summer 2016, the Arizona public utility commission was evaluating a proposal to change the incentive from a percentage of shared savings to a return on program spending on energy efficiency (Arizona Corporation Commission Docket No. E-00000XX-130214).

${ }^{22}$ Mark Newton Lowry and Tim Woolf, Performance-Based Regulation in a High Distributed Energy Resources Future (Berkeley, CA: Lawrence Berkeley National Laboratory, 2016), 
https://emp.lbl.gov/sites/all/files/lbnl-1004130_0.pdfhttps://emp.lbl.gov/sites/all/files/lbnl-1004130_0.pdf (accessed September 14, 2016).

${ }^{23}$ State of New York, REV: Reforming the Energy Vision (Albany: State of New York, 2016), https://www.ny.gov/sites/ny.gov/files/atoms/files/WhitePaperREVMarch2016.pdf (accessed Aug. 30, 2016).

${ }^{24}$ For more information abouton energy service provider models, see James Newcomb, Virginia Lacy, and Lena Hansen, New Business Models for the Distribution Edge: The Transition Fromthe transition from Value Chain to Value Constellation (Denver: Rocky Mountain Institute, 2013), 16, http://www.rmi.org/New_Business_Models (accessed September 14, 2016)..

${ }^{25}$ Nevada Governor's Office of Energy, "New Energy Industry Task Force," http://energy.nv.gov/Programs/New_Energy_Industry_Task_Forcehttp://energy.nv.gov/Programs/New_En ergy_Industry_Task_Force/ (accessed June 14, 2016).

${ }^{26}$ Nathan Cortez, "Regulating Disruptive Innovation," Berkeley Technology Law Journal 29, no. 1 (2014): 175-228, http://scholarship.law.berkeley.edu/cgi/viewcontent.cgi?article=2021\&context=btlj (accessed Sept. 14, 2016).

${ }^{27}$ J.E. Kwoka Jr., "Twenty-Five Years."

${ }^{28}$ Ari Peskoe, "Ratemaking and the Campaign Against Rooftop Solar," Fortnightly Magazine (July 2016). 